\title{
Hunting tactics of the lemon shark, Negaprion brevirostris, in shallow waters of an oceanic insular area in the western equatorial Atlantic
}

\author{
Ricardo C. Garla ${ }^{1,2}$, Otto B. F. Gadig 2 , José Garcia Junior ${ }^{3}$, Leonardo B. Veras ${ }^{4}$ and \\ Domingos Garrone-Neto ${ }^{2,5}$
}

\begin{abstract}
The hunting tactics of lemon sharks, Negaprion brevirostris, are described from underwater and cliff-top observations in the Fernando de Noronha Archipelago, western equatorial Atlantic, Brazil. Two main tactics were observed in the shallow waters of sandy beaches and reefs environments: (i) "substrate inspection" of crevices and holes over rocky and reef bottoms, and (ii) "sardine blitz", which refer to striking schools of fishes (mainly sardines) in the surf zone. The first tactic was restricted to juveniles up to $2 \mathrm{~m}$ of total length, whereas subadult and adult sharks with total length larger than $2 \mathrm{~m}$ displayed the second. As lemon sharks use waters less than $5 \mathrm{~m}$ depth to hunt, perform social behaviours and predator avoidance, results highlight the importance of properly managing these habitats for their conservation, especially in areas where tourism has increased substantially.
\end{abstract}

Keywords: Carcharhinidae, Elasmobranch, Foraging Behaviour, Predation, Predator-prey Interactions.

As táticas de caça do tubarão-limão, Negaprion brevirostris, são descritas a partir de observações subaquáticas e de mirantes no Arquipélago de Fernando de Noronha, no Atlântico ocidental equatorial, Brasil. Duas táticas principais foram observadas em águas rasas de praias arenosas e ambientes recifais: (i) "inspeção do substrato" de fendas e cavidades em fundos recifais e rochosos e (ii) "ataques a sardinhas", que se referem a ataques repentinos a cardumes de peixes (principalmente sardinhas) na zona de arrebentação. A primeira tática esteve restrita a tubarões jovens com até $2 \mathrm{~m}$ de comprimento total, enquanto a segunda foi executada por subadultos e adultos com comprimento total acima de $2 \mathrm{~m}$. Como os tubarões-limão utilizam águas com profundidades inferiores a $5 \mathrm{~m}$ para caçar, realizar interações sociais e evitar predadores, os resultados realçam a importância de se manejar adequadamente estes hábitats para sua conservação, especialmente em áreas onde o turismo tem aumentado substancialmente.

Palavras-chave: Carcharhinidae, Comportamento de forrageamento, Elasmobrânquios, Interação predador-presa, Predação.

\section{Introduction}

Sharks capture prey ranging from plankton to marine mammals using a wide variety of methods such as ram, biting, suction, and filter feeding (Motta, 2004). The main predatory tactics used by that most sharks are stalking and ambush, but a few specialized species (such as the megamouth shark, Megachasma pelagios, and the cookie cutter shark, Isistius brasiliensis) likely use luminescent tissue to lure their prey before attacking (Compagno, 1990; Widder, 1998). A few other species may weaken or incapacitate prey before they consume it, such as the thresher sharks (Alopiidae) that employ tail-slaps to debilitate sardines (Oliver et al., 2013) and the great hammerhead, Sphyrna mokarran, which uses the head to blow and restrain prey on the substrate before biting (Strong et al., 1990). Most species forage alone, but cooperative foraging involving some form of coordinated herding of prey has been reported in several species of sharks (see Motta, Wilga, 2001; Heithaus, 2004; Motta, 2004 for reviews).

The direct observation of sharks in nature is not easy due to their high mobility, low densities, crepuscular and nocturnal habits, and the relatively concealing underwater environment. Thus, such observation is mostly dependent

\footnotetext{
${ }^{1}$ Departamento de Botânica, Ecologia e Zoologia, Universidade Federal do Rio Grande do Norte, 59078-970 Natal, RN, Brazil. rgarla@ hotmail.com (corresponding author)

${ }^{2}$ Laboratório de Pesquisa de Elasmobrânquios e Nécton Marinho, UNESP - Universidade Estadual Paulista, 11330-900 São Vicente, SP, Brazil.gadig@clp.unesp.br

${ }^{3}$ Recursos Pesqueiros, Instituto Federal do Rio Grande do Norte, 59500-000 Macau, RN, Brazil. jose_garciajunior@yahoo.com.br ${ }^{4}$ Museu dos Tubarões, 53990-000 Fernando de Noronha, PE, Brazil. leo@planasub.com.br

${ }^{5}$ Curso de Engenharia de Pesca, UNESP - Universidade Estadual Paulista, 11900-000 Registro, SP, Brazil. garroneneto@registro.unesp.br.
} 
on casual or one-of-a-kind observations of their occurrence and behaviour, making their foraging ecology and predatory behaviour poorly understood. Indeed, most data about the natural predation of sharks comes from anecdotal or opportunistic observations (Motta, 2004).

Knowledge of the predatory behaviour of the lemon shark, Negaprion brevirostris (Poey, 1868), is also scarce. This is a large [at least $340 \mathrm{~cm}$ total length (TL)] inshore Carcharhinidae shark that inhabits the continental and insular shelves in disjoint populations in the western Atlantic (from New Jersey to southern Brazil), eastern Atlantic and eastern Pacific Oceans (Ebert et al., 2013). The lemon shark is listed as Near Threatened by the IUCN Red List (Sundström, 2015) and regarded as Vulnerable along the Brazilian coast following IUCN criteria (Rosa, Gadig, 2008; MMA, 2014).

Previous investigations about the diet and the feeding habits of $N$. brevirostris have focused on juvenile individuals within the nurseries areas of the western North Atlantic. Lemon sharks are piscivorous in this life stage and prey secondarily on benthic crustaceans (Cortés, Gruber, 1990; Wetherbee, 1990; Wetherbee et al., 1990). Recent investigations demonstrate that juveniles of $N$. brevirostris prefer medium sized teleost fishes of the families Scaridae and Gerreidae, but can be opportunists when environmental conditions deteriorate (Newman et al., 2010). There is also an ontogenetic shift from predominantly opportunistic benthic foraging to more selective piscivory (Newman et al., 2011).

Data regarding the diet and hunting behaviour of $N$. brevirostris remain scarce along the continental and insular shelves of the South Atlantic. However, the current conservation status and the reports of population decline and local extinctions of $N$. brevirostris in the western South Atlantic (Rosa, Gadig, 2008; Sundström, 2015) have attracted the interest of scientists and authorities and initiated a national plan for the conservation of this species (and other marine elasmobranchs) in the Brazilian territory (ICMBIO, 2012). These include the incentive for research to assess the ecological requirements of the lemon shark for habitat and prey selection, in order to ensure the effective management and conservation of the species. Herein, the hunting behaviour of juvenile and adult $N$. brevirostris in shallow waters is described in one of its main nurseries areas in the western South Atlantic, aiming to increase the knowledge about the life history of the species.

\section{Material and Methods}

Study site. The study was conducted between 2006 and 2013 in the Fernando de Noronha Archipelago (FEN), which is an isolated group of volcanic islands located in the western South Atlantic, $345 \mathrm{~km}$ off the north-eastern coast of Brazil $\left(03^{\circ} 52^{\prime} \mathrm{W}, 32^{\circ} 25^{\prime} \mathrm{S}\right)$ (Fig. 1). FEN is under the influence of the South Equatorial Current, with mean water temperature of $26^{\circ} \mathrm{C}$ and a tropical oceanic climate with two distinct seasons, a wet season from February to July and a dry season during the rest of the year (see Maida, Ferreira, 1997 for details).

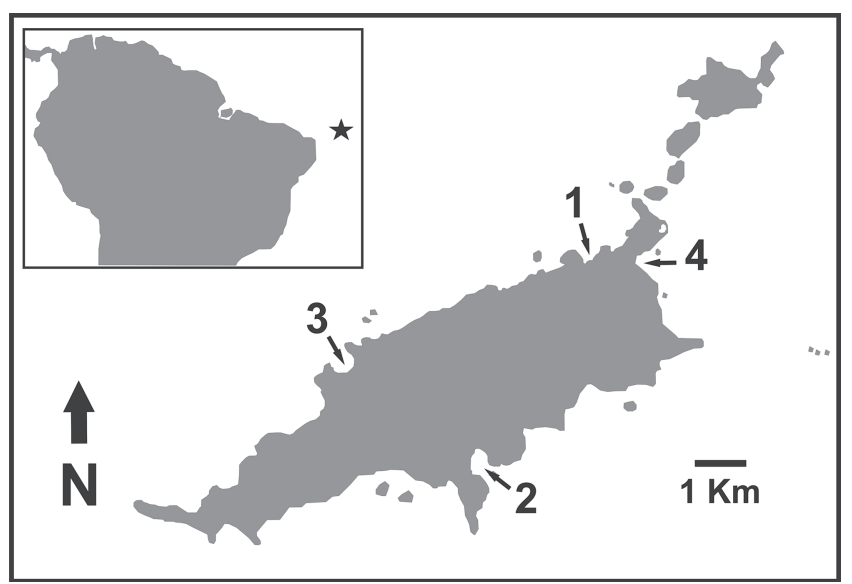

Fig. 1. Fernando de Noronha Archipelago (depicted by the star), $345 \mathrm{~km}$ off the Brazilian coast: 1 and $\mathbf{2}$ indicate sites where juveniles Negaprion brevirostris were observed between 2008 and 2009; 3 and $\mathbf{4}$ indicates sites where subadult and adult individuals were sighted chasing schools of sardines in 2006, 2012 and 2013.

Underwater observations. Snorkelling observations were performed between April 2008 and December 2009 focusing two areas. Site 01, "Biboca", on the leeward side, which comprises a gravel beach bordered by reefs up to a depth of $6 \mathrm{~m}$, subdivided into three zones, reef flat $(0$ to $1.5 \mathrm{~m}$ depth), reef crest $(0.5$ to $3 \mathrm{~m})$ and fore reef $(2$ to $6 \mathrm{~m})$. Site 02, "Sueste", on the windward side, which is an enclosed bay with shallow waters (up to $3 \mathrm{~m}$ depth) with its western and eastern boundaries composed by a more complex rocky bottoms zone (0 to $1.5 \mathrm{~m}$ ), an intermediate complex rocky flat zone (0 to $2 \mathrm{~m})$, and a central less complex sandy substrate zone (0 to $3 \mathrm{~m})$. Observational sessions were made through strip transects $(300 \times 8 \mathrm{~m})$ between 0.5 to $6 \mathrm{~m}$ depth (modified from Helfman, 1992). Each census lasted 40 minutes and subsequent censuses were always spaced by at least 1 hour intervals. Censuses were performed parallel to the shore, and conducted within the boundaries of each zone by a diver in slow and constant speed, with no changes in direction or itinerary. The order and direction of visual censuses were randomized to minimize influences of the observer's presence in the hunting behaviour of juvenile lemon sharks. All sampling was performed during daylight hours (06:00 to 18:00 hours), in absence of large waves $(>1 \mathrm{~m})$, and with water visibility of at least $4 \mathrm{~m}$. The following information was collected: shark presence, time of first shark sighting, number of individuals, if sharks were solitary or in groups, approximate total length (TL) and behaviour displayed.

The "ad libitum" sampling method (Martin, Bateson, 1986), in which the observer recorded all the behaviours of individuals or groups encountered, was employed for both the underwater and cliff-top observation sessions (described below). Size estimates of TL in a scale of $0.5 \mathrm{~m}$ were calibrated against objects of known size, such as patch reefs or rocky boulders. The sexual maturity was not estimated in a fine scale level since the previous published data on the 
size at maturity in both sexes range from 2.26 to $2.45 \mathrm{~m} \mathrm{TL}$ (Castro, 2011). Thus, specimens ranging from 0.6 to $2 \mathrm{~m}$ TL were considered juveniles, and individuals larger than 2 m TL were regarded as subadults or adults (Castro, 2011). Due to the possible bias, especially resulting from the clifftop observations, the sex of the sharks was not determined. Digital photographs and video-records were taken whenever possible to check visual observations.

Cliff-top observations. Additional records of the foraging behaviour of $N$. brevirostris were obtained in February 2006, January 2012 and January 2013 in sites 03 and 04, while checking for the presence or absence of sharks at two observatories located on the top of cliffs (about $50 \mathrm{~m}$ above sea level and $200 \mathrm{~m}$ distance from targets), where adult individuals can be observed from land at high tides. Observers using 10x50 binoculars and digital cameras with $500 \mathrm{~mm}$ telephoto lens started the observation sessions at mid high tide and usually left the cliff four hours later. The following information was collected: shark presence, time of first shark sighting, number of individuals, if sharks were solitary or in groups, approximate TL and behaviour displayed.

Data analysis. Differences in the number of strikes against the schools of fishes among time of the day and seasons were investigated by contingency Chi-square tests. Statistical analyses were performed with SPSS software version 13.0 for Windows, adopting a significance level of 0.5 . Data were log $(\mathrm{x}+1)$ transformed to normalize and homogenize variances. Data normality was verified through Kolmorogov-Smirnov test and data homoscedasticity with Levene's test (Zar, 1999).

\section{Results}

Underwater observations. Approximately 660 hours of underwater observations were performed in sites 1 and 2 (Tab. 1). In those occasions only lemon sharks ranging between 0.6 to $1.5 \mathrm{~m}$ TL were sighted. A total of 136 events of hunting behaviour were recorded in site 1:89 of those events (65.4\%) were inspection of crevices or holes and 47 (34.6\%) were strikes towards schools of sardines, Harengula clupeola
(Clupeidae) (Fig. 2a). The hunting behaviour of $N$. brevirostris in site 1 did not differ between wet and dry seasons $\left(\chi^{2}=2.44\right.$, $\mathrm{P}=0.211)$, and between morning and afternoon periods $\left(\chi^{2}\right.$ $=0.27, \mathrm{P}=0.764)$. Only ten strikes of $N$. brevirostris against schools of sardines were recorded in site 2 (Fig 2a). As observed in site 1 , the frequency of strikes in site 2 did not differ between wet and dry seasons $\left(\chi^{2}=4.01, \mathrm{P}=0.308\right)$, and between morning and afternoon periods $\left(\chi^{2}=0.53, \mathrm{P}=0.925\right)$. Strikes on schools of sardines were made by solitary sharks in 49 of the 60 records while two to three sharks performed this behaviour in the remaining events. Attacks towards sardines were exclusively observed in the shallower sections of both sites ( $\leq 1 \mathrm{~m}$ depth), which are only accessible to sharks during the high tides. The two hunting tactics recorded in sites 1 and 2 were named as "substrate inspection" and "sardine blitz" (see Tab. 2 for behavioural descriptions and Fig. 2b-d for the records of behaviours per site, daytime and TL).

After performing "substrate inspection" the shark quickly turned the body out of the hole or crevice and resumed a "patrolling behaviour" (sensu Myrberg, Gruber, 1974). The quick movements of those inspections suspended substrate and formed discrete clouds of sediment around the shark, preventing the observer to confirm the predation event and the type of prey consumed. However, in one event it was possible to observe a shark swimming out of a crevice with an octopus tentacle in its mouth, indicating the possible consumption of this type of prey through "substrate inspection".

"Sardine blitz" was observed when sharks approached the sardine schools performing "patrolling behaviour" and when at a distance of less than $2 \mathrm{~m}$, suddenly stroked the fishes with short bursts of speed towards a small part of the school (Figs. 3a-b). As a result, many sardines escaped with a "flash expanse behaviour" (sensu Magurran, Pitcher, 1987) (as shown in photograph S1 - Available only as online supplementary file accessed with the online version of the article at http://www.scielo.br/ni) swimming rapidly out of the point of attack. However, due to the quick strike (in a millisecond scale) and unfavourable position of the observer, usually hidden by the sharks or part of the school, it was not possible to evaluate the predatory effectiveness of this hunting tactic.

Tab. 1. Sampling effort per period of the diel cycle in the Fernando de Noronha Archipelago, Brazil. * $M=$ morning (06:00 to 12:00 h); A = afternoon (12:01 to 18:00 h); Wet season (from February to July), Dry season (August to July).

\begin{tabular}{|c|c|c|c|c|c|c|}
\hline \multicolumn{7}{|c|}{ Snorkeling censuses (40 min duration each) } \\
\hline & \multicolumn{3}{|c|}{2008} & \multicolumn{3}{|c|}{2009} \\
\hline & Apr-May & Jul & Dec & Jan & Jul & Dec \\
\hline Site 1 & $89(48 \mathrm{M}, 41 \mathrm{~A})$ & $88(45 \mathrm{M}, 43 \mathrm{~A})$ & $88(46 \mathrm{M}, 42 \mathrm{~A})$ & $93(48 \mathrm{M}, 45 \mathrm{~A})$ & $91(49 \mathrm{M}, 42 \mathrm{~A})$ & $89(46 \mathrm{M}, 43 \mathrm{~A})$ \\
\hline Site 2 & $73(36 \mathrm{M}, 37 \mathrm{~A})$ & $73(38 \mathrm{M}, 35 \mathrm{~A})$ & $75(40 \mathrm{M}, 35 \mathrm{~A})$ & $83(41 \mathrm{M}, 42 \mathrm{~A})$ & $76(35 \mathrm{M}, 41 \mathrm{~A})$ & $83(40 \mathrm{M}, 43 \mathrm{~A})$ \\
\hline Total censuses & 162 & 161 & 163 & 176 & 167 & 172 \\
\hline \multicolumn{7}{|c|}{ Cliff-top observation sessions ( $4 \mathrm{~h}$ duration each) } \\
\hline & 2006 & 2007 & 2008 & 2011 & 2012 & 2013 \\
\hline & Jan-Feb & Jan-Feb & Jan-Feb & Jan-Feb & Jan-Feb & Jan-Feb \\
\hline Site 3 & $11(6 \mathrm{M}, 5 \mathrm{~A})$ & $10(5 \mathrm{M}, 5 \mathrm{~A})$ & $10(5 \mathrm{M}, 5 \mathrm{~A})$ & $9(5 \mathrm{M}, 4 \mathrm{~A})$ & $11(6 \mathrm{M}, 5 \mathrm{~A})$ & $12(6 \mathrm{M}, 6 \mathrm{~A})$ \\
\hline Site 4 & $9(4 \mathrm{M}, 5 \mathrm{~A})$ & $10(5 \mathrm{M}, 5 \mathrm{~A})$ & $11(7 \mathrm{M}, 4 \mathrm{~A})$ & $10(5 \mathrm{M}, 5 \mathrm{~A})$ & $10(5 \mathrm{M}, 5 \mathrm{~A})$ & $12(8 \mathrm{M}, 4 \mathrm{~A})$ \\
\hline Total sessions & 20 & 20 & 21 & 19 & 21 & 24 \\
\hline
\end{tabular}


a

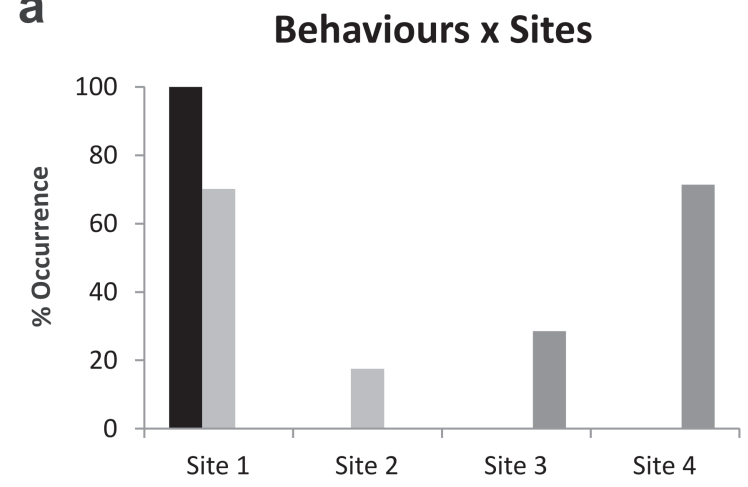

C

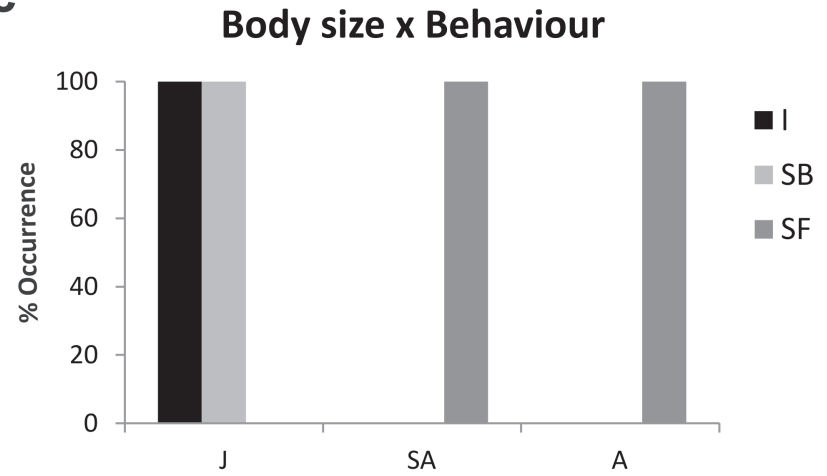

b

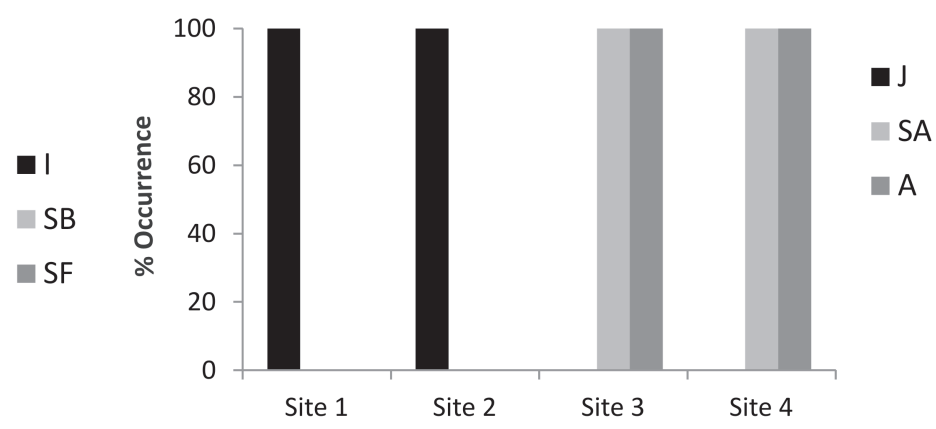

d

\section{Behaviours x Daytime}

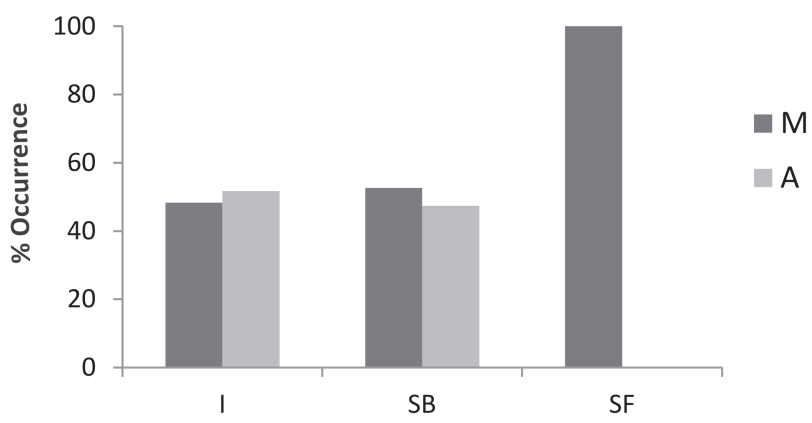

Fig. 2. Percentage of occurrence of hunting behaviours of Negaprion brevirostris per a. site, b., $\mathbf{c}$. body size and $\mathbf{d}$. time of the day in Fernando de Noronha Archipelago. I: substrate inspection; SB: sardine blitz; SF: sand fishing; M: morning, A: afternoon; J: juvenile; SA: subadult; A: adult.

Tab. 2. Ethogram of snorkeling (S) and cliff-top (C) observed behaviours of Negaprion brevirostris in Fernando de Noronha Archipelago, Brazil (see Fig. 1 for location of sites).

\begin{tabular}{|c|c|c|c|c|}
\hline Behaviour category & $\begin{array}{l}\text { Size class, sites } \\
\text { observed }\end{array}$ & $\begin{array}{l}\text { No., type and duration } \\
\text { of observations }\end{array}$ & Behaviour description & Habitat type/ Depth \\
\hline Substrate inspection & $\begin{array}{c}\text { Juveniles and } \\
\text { subadults less than } 2 \\
\text { m TL, sites } 1 \text { and } 2\end{array}$ & $\begin{array}{c}89(\mathrm{~S}), \text { mean duration } \\
8.5 \mathrm{seg}(4-15 \mathrm{seg})\end{array}$ & $\begin{array}{l}\text { A shark approached a hole or crevice poking the substrate } \\
\text { with its rostrum. The shark inclined the body forward and } \\
\text { introduced its head and/or anterior part of the body in the } \\
\text { hole performing abrupt lateral undulations to adjust the } \\
\text { anterior part of the body to the hole and keep the body } \\
\text { in position. }\end{array}$ & $\begin{array}{l}\text { Reef flat and front } \\
\text { reef, } 0.5 \text { to } 1.5 \mathrm{~m}\end{array}$ \\
\hline Sardine blitz & $\begin{array}{c}\text { Juveniles and } \\
\text { subadults less than } 2 \\
\text { m TL, sites } 1 \text { and } 2\end{array}$ & $\begin{array}{c}47(\mathrm{~S}, \mathrm{C}), \text { mean duration } \\
15.1 \mathrm{seg}(4-30 \mathrm{seg})\end{array}$ & $\begin{array}{l}\text { One or more sharks approached the sardine schools } \\
\text { exhibiting usual "patrolling behaviour" and when at a } \\
\text { distance of less than } 2 \mathrm{~m} \text {, suddenly stroked the fishes with } \\
\text { short bursts of speed towards a small part of the school. }\end{array}$ & $\begin{array}{l}\text { Reef and rocky flats, } \\
\text { sandy bottom with } \\
\text { sparse reefs and } \\
\text { rocks, } 0.5 \text { to } 1.5 \mathrm{~m}\end{array}$ \\
\hline Sand hunting & $\begin{array}{c}\text { Subadults larger than } \\
2 \text { TL and adults, sites } \\
3 \text { and } 4\end{array}$ & $\begin{array}{l}12(\mathrm{C}), \text { mean duration } \\
37.7 \mathrm{~min}(17-38 \mathrm{~min})\end{array}$ & $\begin{array}{l}\text { Sharks larger than } 2 \mathrm{~m} \text { TL were initially observed } \\
\text { performing "patrolling behaviour" at the deeper near- } \\
\text { shore section of the beach }(\sim 1.5 \mathrm{~m} \text { depth), immediately } \\
\text { beyond the surf zone. Similar to the "sardine blitz" } \\
\text { described above, but sharks only attacked the schools of } \\
\text { sardines in the swash zone }(0.3-1 \mathrm{~m} \text { depth }) \text { immediately } \\
\text { after the waves have broken. }\end{array}$ & $\begin{array}{c}\text { Sandy beach, } 0.3 \text { to } \\
1.5 \mathrm{~m}\end{array}$ \\
\hline
\end{tabular}

Cliff-top observations. A total of 501 hours of cliff-top observations were conducted in sites 3 and 4 (Tab. 1). The observations resulted in the record of a third hunting tactic in February $2006(\mathrm{~N}=1)$, January $2012(\mathrm{~N}=1)$ and January $2013(\mathrm{~N}=5)$. Named here as "sand fishing" (Tab. 2), this hunting tactic was considered a variant of "sardine blitz" and was observed only in subadult and adult specimens (Fig. 2d). In site 3, records were made in February 2006 and January 2012, between 06:00h and 08:00h. Three sharks with TL larger than $2 \mathrm{~m}$ were sighted in February 2006 and two individuals of similar size were observed in January 2012. In both occasions the sharks were initially observed performing "patrolling 
behaviour" at the deeper near-shore section of the beach $(\sim 1.5$ $\mathrm{m}$ depth), immediately beyond the surf zone (Fig. 4a). Sharks were completely surrounded by the school of sardines, which separated ahead of the shark and then closed back together behind it, creating a sardine-free vacuole around the shark ("vacuole behaviour" sensu Magurran, Pitcher, 1987) (Fig. 4b and photograph S2 - Available only as online supplementary file accessed with the online version of the article at http:// www.scielo.br/ni). Sharks performed sinuous movements from the surf zone to the shallower swash zone (0.3-1 m depth), but only attacked the schools of sardines with short bursts of speed immediately after the waves have broken (Fig. 4c).

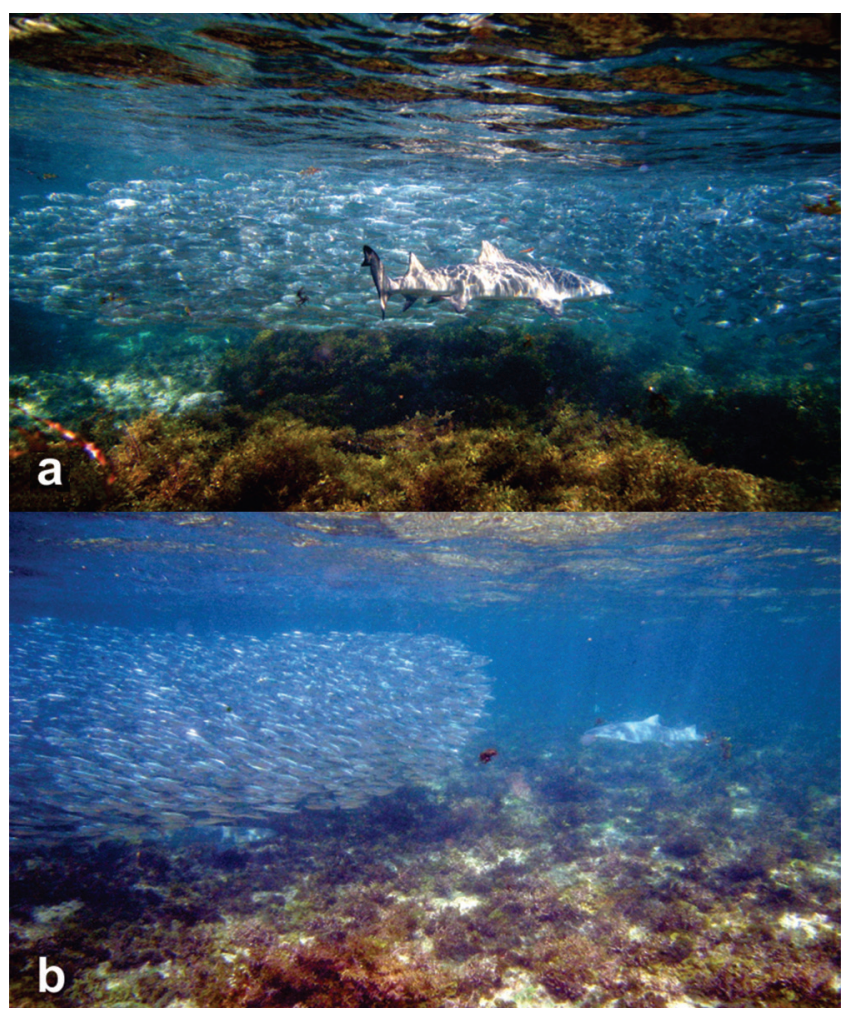

Fig. 3. a. and b. Juvenile Negaprion brevirostris in site 1 seconds before striking a school of sardines.

In site 4, "sand fishing" was observed in January 2013 during five consecutive days, between 05:50h and 06:30h. At least 15 lemon sharks ranging from 2 to $2.5 \mathrm{~m}$ TL were observed exposing their dorsa in shallow waters of the swash zone (0.2$0.5 \mathrm{~m}$ depth), between 1 to $5 \mathrm{~m}$ from the shoreline, almost stranding in some occasions (Fig. 5 and photograph $\mathbf{S 3}$ and videos S4 and S5 - Available only as online supplementary files accessed with the online version of the article at http://www. scielo.br/ni). The sharks swam slowly, but suddenly performed faster and frenetic movements towards the shoreline, suggesting that they were attacking fishes. At least in three occasions, the attacks were performed by five to seven individuals close to each other, in a line formation. Due to the time (i.e. dawn) and to the usually rough and turbid waters in this site, observations of the underwater environment from land were not possible. However, the observation of sardines thrown on the beach by the waves suggested the presence of schools cornered by the sharks against the shoreline. This was further reinforced by the presence of marine birds such as brown boobies, Sula leucogaster (Sulidae), and black noddies, Anous minutus (Laridae), in feeding activity close to the sharks. At least in two occasions it was possible to observe the sardines jumping outside the water when a shark approached, possibly in an attempt to escape (video S6 - Available only as online supplementary file accessed with the online version of the article at http://www.scielo.br/ni). Those interactions where more intense when light levels were low, after what sharks and marine birds dispersed suggesting that the schools of fishes had abandoned the area or moved to deeper waters. In both sites, the presence of sharks closed to the shoreline performing "sand fishing" were only observed at high tides in the early morning, during the new or full moons.

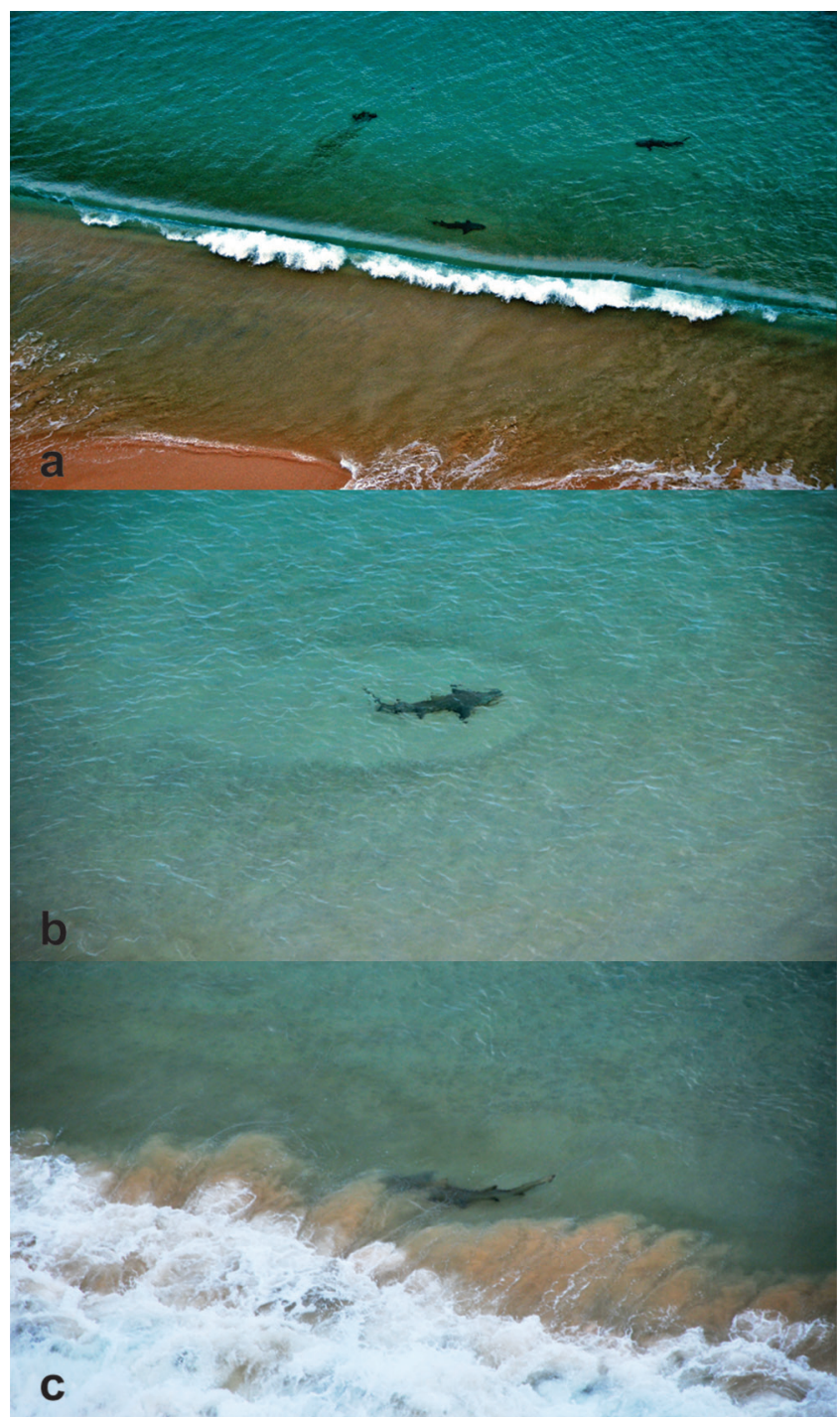

Fig. 4. a. Two Negaprion brevirostris (TL $>2 \mathrm{~m}$ ) patrolling the shoreline near the surf zone of site 03 in January 2012. b. Lemon shark surrounded by a school of sardines displaying "vacuole" behaviour (sensu Magurran, Pitcher 1987). c. The same shark seconds before striking the school of sardines hidden by sand suspension (Photographs by José Carlos Marenga). 


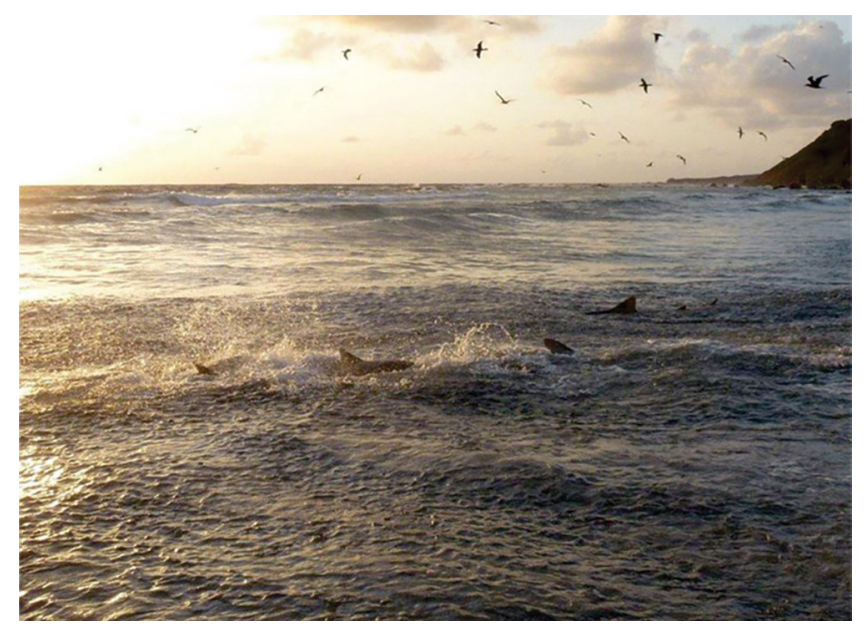

Fig. 5. Three Negaprion brevirostris (TL $>2 \mathrm{~m}$ ) chasing schools of sardines in waters of the swash zone (0.2-0.5 $\mathrm{m}$ depth) during sunrise hours in site 4 in January 2013, and boobies, Sula leucogaster, and black noddies, Anous minutus, in feeding activity (Photograph by Leonardo Veras).

\section{Discussion}

Observations of natural predation by large shark species are not common, but they can provide important insights into the behaviour of these apex predators (Martin et al., 2005). Although it was not possible to observe the consumption of prey in the field, the repeated and stereotyped movements recorded suggest that lemon sharks were attempting to feed in very shallow waters of the surf and swash zones $(\leq 1 \mathrm{~m}$ depth) of FEN. The events involving the hunting behaviour of juvenile, subadult and adult individuals of $N$. brevirostris were observed during distinct times of the day and in different sites of the archipelago. However, all size classes adopted similar hunting tactics in shallow waters of sandy beaches and reef environments.

The "digging behaviour" of juvenile lemon sharks reported by Guttridge et al. (2012) is probably similar to the "substrate inspection" herein recorded, except that the first tactic was observed only over sandy bottom. Both behaviours reinforce the benthic feeding habits of juvenile lemon sharks. Moreover, the behaviour of juvenile sharks chasing schools of sardines further indicates an ontogenetic shift in the diet from benthic foraging to nektonic and water column prey, as demonstrated by Newman et al. $(2010,2011)$.

Previous investigations have reported the habit of the lemon shark to herd schools of fish against the shoreline (Wetherbee, 1990; Morrissey, 1990; Reyer et al., 2008), and to patrol shorelines at low light levels in order to intercept fishes moving between shallow waters and adjacent areas (Hammerschlag et al., 2010). However, photographic records and detailed descriptions as presented here are not available in the literature.

The "sand fishing" demonstrates that lemon sharks can take advantage of the water turbidity and turbulence produced by waves to perform a more efficient approximation of the schools of sardines (and possibly other small fishes). As schools of clupeid fishes generally disperse at dusk and aggregate at dawn (Blaxter, Hunter, 1982), lemon sharks possibly obtain an additional advantage attacking prey when their aggregations are larger. This hunting tactic may prevent the escape of prey and increase capture success, and may also explain the common name given by FEN islanders to the lemon shark: "papa-areia" (in the Brazilian language), which literally means "sand-eater" (RC Garla, oral communication August 2016), demonstrating the perception of local fishermen of such behaviour. The ability of larger lemon sharks to use environmental conditions and coordinated group formation to attack prey indicates learning and support the argument that juveniles need to develop predation skills and senses associated with prey search and capture as they grown (Beulig, 1982; Wetherbee et al., 1990).

Several shark species have been observed displaying some form of coordinated herding and driving of prey, including Carcharhinus melanopterus, C. longimanus and $N$. brevirostris (Carcharhinidae), Carcharias taurus (Odontaspididae), and Alopias spp. (Alopiidae) (Motta, Wilga, 2001; Motta, 2004). The "sand fishing" herein reported also raise the possibility of cooperative foraging in $N$. brevirostris. However, some authors suggest that those events may not be cooperative and simply reflect aggregations of animals feeding on common prey (Heithaus, 2004; Motta, 2004). Although it was not possible to measure whether each shark increase its individual intake of prey, the observed attacks of lemon sharks in line formation possibly lead to a breaking up of the schools into smaller parts.

The records presented here have implications for identifying essential habitats for $N$. brevirostris. As reported in other sites of the western Atlantic, lemon sharks in FEN have a preference for shallow waters $<5 \mathrm{~m}$ to perform social behaviours, which are also used by juveniles as feeding and predator avoidance habitats (Gruber et al., 1988; Wetherbee et al., 2007). FEN has extensive protected areas that include such habitats and represents one of the most important breeding areas of $N$. brevirostris in the western Atlantic (Freitas et al., 2006; Garla et al., 2009). Nevertheless, tourism activity there has substantially increased from 10,094 tourists per year in 1992 to 62,551 tourists per year in 2002 (Moreira et al., 2011), especially in N. brevirostris critical areas, such as the shorelines of sand beaches and reef environments. This abrupt increase highlights the importance of properly managing the shoreline habitats to maintain tourism impacts to a minimum. The main tourism activities in the studied sites start at 8:00h and include boat traffic and snorkelling. However, small groups of tourists can be occasionally observed in those sites before this time, especially in site 3 . While conducting cliff-top surveys it was observed that sharks usually leave the swash zone immediately after tourists enter the water. This happens because most tourists usually enter the water in groups, shouting and with sudden movements. However, after 8:00h sardines and sharks generally retreat to deeper waters. In this 
sense, recommended management actions could include the creation and dissemination of a snorkeling code of conduct and/or the prohibition of aquatic activities (snorkelling and boat traffic) in depths $<5 \mathrm{~m}$ between 06:00 and 08:00h. As the tourism activity is minimal in the early morning, these measures would help to prevent the disturbance of the sharks at the shoreline and would have little impact on the tourism activity, which is essential to FEN's economy. Those would be simple and low cost management actions, with positive impacts for sharks and also for tourists, who would have a chance to better enjoy the interactions with the animals.

\section{Acknowledgments}

The authors are grateful to the Administration of Fernando de Noronha (ATDEFN) and the Brazilian Environmental Agency (ICMBio) for research permits and tax exemptions. José Carlos Marenga provided digital photographs and allowed their use for research purposes.

\section{References}

Beulig A. Social and experimental factors in the responsiveness of sharks to sound. Fla Sci. 1982; 45(1):2-10.

Blaxter JHS, Hunter JR. The biology of the clupeoid fishes. Adv Mar Bio. 1982; 20:1-223.

Castro JI. Sharks of the North American waters. New York: Oxford University Press; 2011.

Compagno LJV. Relationships of the megamouth shark, Megachasma pelagios (Lamniformes: Megachasmidae), with comments on its feeding habits. In: Pratt HL, Jr., Gruber SH, Taniuchi T, editors. Elasmobranchs as Living Resources: Advances in the Biology, Ecology, Systematics, and the Status of the Fisheries. Washington (DC): National Marine Fisheries Service; 1990. p.357-379. (NOAA Technical Report NMFS; no. 90).

Cortés E, Gruber SH. Diet, feeding habits and estimates of daily ration of young lemon sharks, Negaprion brevirostris (Poey). Copeia. 1990; (1):204-18.

Ebert DA, Fowler S, Compagno LVJ. Sharks of the world: A fully illustrated guide. Plymouth: Wild Nature Press; 2013.

Freitas RHA, Rosa RS, Gruber SH, Wetherbee BM. Early growth and juvenile population structure of lemon sharks Negaprion brevirostris in the Atol das Rocas Biological Reserve, off north-east Brazil. J Fish Biol. 2006; 68(5):1319-32.

Garla RC, Garcia Júnior J, Veras LB, Lopes NP. Fernando de Noronha as an insular nursery area for lemon sharks, Negaprion brevirostris, and nurse sharks, Ginglymostoma cirratum, in the equatorial western Atlantic Ocean. Mar Biodivers Rec. 2009; 2:e109.

Gruber SH, Nelson DR, Morrissey JF. Patterns of activity and space utilization of lemon sharks, Negaprion brevirostris, in a shallow Bahamian lagoon. Bull Mar Sci. 1988; 43(1):61-76.

Guttridge TL, Gruber SH, Franks BR, Kessel ST, Gledhill KS, Uphill J, Krause J, Sims DW. Deep danger: intra-specific predation risk influences habitat use and aggregation formation of juvenile lemon sharks Negaprion brevirostris. Mar Ecol Prog Ser. 2012; 445:279-91.
Hammerschlag N, Heithaus MR, Serafy JE. Influence of predation risk and food supply on nocturnal fish foraging distributions along a mangrove-seagrass ecotone. Mar Ecol Prog Ser. 2010; 414:223-35.

Heithaus MR. Predator-prey interactions. In: Carrier JC, Musick JA, Heithaus MR, editors. Biology of Sharks and their Relatives. Boca Raton; London; New York: CRC Press; 2004. p.487-521. (CRC Marine Biology Series).

Helfman GS. Underwater Methods. In: Nielsen LA, Johnson DL, editors. Fisheries Techniques. 4th ed, Pennsylvania: Am Fish Soc; 1992. p.348-69.

Instituto Chico Mendes de Conservação da Biodiversidade (ICMBIO), Ministério do Meio Ambiente (MMA). Plano de Ação Nacional para a Conservação dos Tubarões. [Brazilian Action Plan for Shark Conservation]. 2012 [Date of access - 10 August 2016]. Available from: http://www.icmbio.gov.br/portal/ biodiversidade/fauna-brasileira/plano-de-acao/2839-plano-deacao-nacional-para-a-conservacao-dos-tubaroes.html/

Magurran AE, Pitcher TJ. Provenance, shoal size and the sociobiology of predator-evasion behaviour in minnow shoals. Proc R Soc B. 1987; 229(1257):439-65.

Maida M, Ferreira BP. Coral reefs of Brazil: an overview. Proc. $8^{\text {th }}$ Int Coral Reef Symp. 1997; 1:263-74.

Martin P, Bateson P. Measuring behaviour: An introductory guide. Cambridge: Cambridge University Press; 1986.

Martin RA, Hammerschlag N, Collier RS, Fallows C. Predatory behaviour of white sharks (Carcharodon carcharias) at Seal Island, South Africa. J Mar Biol Assoc UK. 2005; 85:1121-35.

Ministério do Meio Ambiente (MMA). Portaria n ${ }^{\circ} 445$, de 17 de dezembro de 2014. 2014 [Date of access - 10 August 2016]. Available from: http://www.icmbio.gov.br/portal/images/ stories/biodiversidade/fauna-brasileira/avaliacao-do-risco/ PORTARIA_N\%C2\%BA_445_DE_17_DE_DEZEMBRO DE 2014.pdf

Moreira JC, Reis AC, Silva Júnior JM. Fernando de Noronha Archipelago: community perspectives on tourism. 7th International Small Islands Conference. 2011; 34-41.

Morrissey JF. Home range of juvenile lemon sharks. In: Gruber $\mathrm{SH}$, editor. Discovering Sharks. Highlands: American Littoral Society; 1990. p.85-86.

Motta PJ. Prey capture behaviour and feeding mechanisms of elasmobranchs. In: Carrier JC, Musick JA, Heithaus MR, editors. Biology of Sharks and their Relatives. Boca Raton; London; New York, CRC Press; 2004. p.165-202. (CRC Marine Biology Series).

Motta PJ, Wilga CD. Advances in the study of feeding behaviours, mechanisms, and mechanics of sharks. Environ Biol Fishes. 2001; 60(1):131-56.

Myrberg AA, Jr., Gruber SH. The behavior of the bonnethead shark, Sphyrna tiburo. Copeia. 1974; (2):358-74.

Newman SP, Handy RD, Gruber SH. Diet and prey preference of juvenile lemon sharks Negaprion brevirostris. Mar Ecol Progr Ser. 2010; 398:221-34.

Newman SP, Handy RD, Gruber SH. Ontogenetic diet shifts and prey selection in nursery bound lemon sharks, Negaprion brevirostris, indicate a flexible foraging tactic. Environ Biol Fishes. 2011; 95(1):115-26. 
Oliver SP, Turner JR, Gann K, Silvosa M, D’Urban Jackson T. Thresher Sharks Use Tail-Slaps as a Hunting Strategy. PLoS ONE [serial on the Internet]. 2013 Jul 10 [Date of access - 10 August 2016; 8(7):e67380. Available from: http://journals. plos.org/plosone/article?id=10.1371/journal.pone.0067380 DOI: http://dx.doi.org/10.1371/journal.pone.0067380

Reyier EA, Adams DH, Lowers RH. First evidence of a high density nursery ground for the lemon shark, Negaprion brevirostris, near Cape Canaveral, Florida. Fla Sci. 2008; 71(2):134-48.

Rosa RS, Gadig OBF. Negaprion brevirostris. In: Machado ABM, Drummond GM, Paglia AP, editors. Livro vermelho da fauna brasileira ameaçada de extinção . Brasília: MMA, Belo Horizonte: Fundação Biodiversitas; 2008. p.22. vol. 2.

Strong WR, Jr., Snelson FF, Jr., Gruber, SH. Hammerhead shark predation on stingrays: an observation of prey handling by Sphyrna mokarran. Copeia. 1990; (3):836-40.

Sundström, LF. Negaprion brevirostris. The IUCN Red List of Threatened Species. 2015. Available from: http://www. iucnredlist.org/details/39380/0

Wetherbee BM. Feeding biology of sharks. In: Gruber, SH, editor. Discovering Sharks. Highlands: American Littoral Society; 1990. p.74-76.
Wetherbee BM, Gruber SH, Cortes E. Diet, feeding habits, digestion and consumption in sharks, with special reference to the lemon shark, Negaprion brevirostris. In: Pratt HL, Jr., Gruber SH, Taniuchi T, editors. Elasmobranchs as Living Resources: Advances in the Biology, Ecology, Systematics, and the Status of the Fisheries. Washington (DC): National Marine Fisheries Service; 1990. p.29-47. (NOAA Technical Report NMFS; no. 90).

Wetherbee BM, Gruber SH, Rosa RS. Movement patterns of juvenile lemon sharks, Negaprion brevirostris, within Atol das Rocas, Brazil: a nursery characterized by tidal extremes. Mar Ecol Prog Ser. 2007; 343:283-93.

Widder EA. A predatory use of counterillumination by the squaloid shark, Isistius brasiliensis. Environ Biol Fishes. 1998; 53(3):267-73.

Zar JH. Biostatistical Analysis. 4th ed. New Jersey: Prentice Hall; 1999.
Submitted August 22, 2016 Accepted January 25, 2017 by Fernando Gibran 